\title{
JUURNAL.RU
}

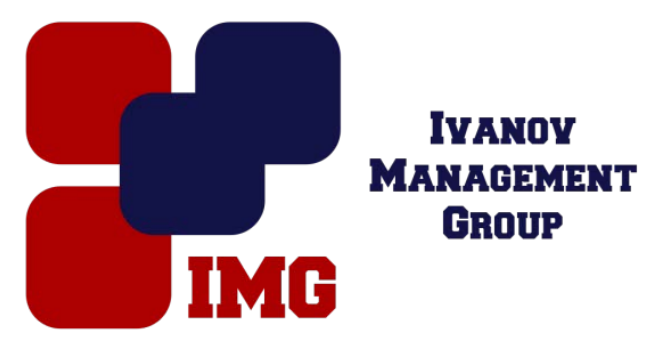

Туркова Н.Ю., Сатюков А.Б., Гончаров В.О.

Оренбургский государственный университет

Оренбург, Россия

doi: 10.18411/lj-28-02-2017-3-11

idsp 000001:lj-28-02-2017-3-11

\section{Современные методы и средства ямочного ремонта дорожных покрытий}

\section{Аннотация}

В данной статье рассматриваются современные методы и средства ямочного ремонта дорожных покрытий. Актуальной задачей в настоящее время считается обеспечение возможности круглогодичного проведения работ по строительству и ремонту дорожных асфальтобетонных покрытий и повышение их долговечности.

Ключевые слова: автомобильная дорога, ямочный ремонт, асфальтобетонная смесь, струйно-инъекционный метод, литой асфальт.

Автомобильная дорога, как любое другое инженерное сооружение, рассчитана на определенный срок службы, в течение которого она подвергается воздействиям транспорта и погодно-климатических факторов (влага, температура). Самым первым и наиболее незащищенным ее элементом, испытывающим такие воздействия, является асфальтобетонное (в большинстве своем) покрытие.

В результате перегрузок покрытия, износа и старения его материалов, на покрытии с течением времени возникают всевозможные дефекты, деформации и разрушения (неровности, трещины, сколы, выбоины, ямы и т.п.).

Асфальтирование и ремонтные работы дорожного покрытия осуществляются различными методами, средствами и материалами, в совокупности определяющими качество, срок службы и стоимость, т.е. эффективность таких ремонтных работ. Главная цель этих работ - обеспечить на эксплуатируемой дороге безопасное движение автомобильного транспорта с установленным скоростным режимом.

Ремонтные работы на покрытии планируются и выполняются чаще всего весной с наступлением устойчивой теплой (не ниже плюс $5{ }^{\circ} \mathrm{C}$ ) и сухой погоды, хотя порой может возникать потребность в проведении и срочного внепланового или аварийного ремонта практически в любое время года и при любых погодных условиях.

При текущем ремонте покрытий, по мере надобности, могут выполнятся следующие виды работ:

- ямочный ремонт (ликвидация ям, выбоин, сколов); 
- заделка трещин;

- асфальтирование - поверхностная обработка или укладка тонких верхних слоев покрытия (ковриков износа).

Основные виды ямочного ремонта осуществляются с применением следующих материалов и технологий:

- горячая асфальтобетонная смесь;

- холодная асфальтобетонная смесь;

- применением литого асфальтобетона;

- инфракрасный ремонт асфальта;

- по струйно-инъекционной холодной технологии.

Выбор технологического метода ямочного ремонта должен отвечать следующим требованиям или критериям:

- высокое качество заделки дефекта, соответствующее показателям плотности, прочности, ровности и шероховатости основной части покрытия;

- продолжительный срок службы отремонтированного места;

- наличие или доступность требуемых материалов, машин

- и установок для выполнения ремонта по выбранному методу;

- сложность или простота реализации намеченного метода ремонта в различных погодных условиях;

- оперативность открытия движения транспорта по месту ремонта;

- низкая стоимость или высокая экономичность ремонтных работ.

В течение многих лет дорожно-ремонтные работы признавались процессом сезонным, строго зависимым от температуры воздуха и влажности дорожного покрытия.

Актуальной задачей в настоящее время считается обеспечение возможности круглогодичного проведения работ по строительству и ремонту дорожных асфальтобетонных покрытий и повышение их долговечности.

Сегодня возможно применение новой технологии ямочного ремонта холодными асфальтобетонными смесями.

Холодная асфальтобетонная смесь бывает нескольких видов:

- смесь на эмульсии немедленного применения;

- холодные эмульсионно-минеральные асфальтобетонные смеси;

- холодная складируемая (пакетируемая) органоминеральная смесь и другие виды смесей.

Технология ремонта асфальтобетонных покрытий с применением холодных складируемых органоминеральных смесей позволяет проводить ямочный ремонт в сухую погоду при среднесуточной температуре воздухадо минус $10^{\circ} \mathrm{C}$.

Работы по устранению выбоин на поврежденном участке покрытия могут выполняться одним из следующих способов:

- с разделкой покрытия и удаления старого материала;

- без разделки покрытия.

Холодная складируемая органоминеральная смесь способна храниться до 2 месяцев, в упаковке до 8 месяцев без какого-либо изменения ее эксплуатационных качеств. Она не требует при укладке квалифицированной рабочей силы и специальной техники, может доставляться к месту ремонта небольшими партиями, в связи с чем, появляется возможность проводить оперативный ремонт 
при образовании незначительных выбоин и, тем самым, не давать им увеличиваться.

Существенным аргументом между горячей асфальтобетонной смесью и холодной складируемой органоминеральной смесью выступает высокая цена последнего.

Среди прочих минусов является значительно меньшая сопротивляемость сдвигу мест ремонта холодными органоминеральными смесями, что исключает их применение при ремонте дефектов дорожного полотна в местах торможения, на перекрестках и автобусных остановках.

Независимость от погодных условий и другие преимущества позволяют холодной асфальтобетонной смеси составить достойную конкуренцию традиционной горячей технологии.

Также возможно найти альтернативный вариант решения дорожной проблемы. Все активнее начинает использоваться литой асфальт, в своей сфере способный составить достойную конкуренцию всем прочим технологиям.

Литой асфальт - горячая смесь тестообразной консистенции, состоящая из высоковязкого твердого битума, большого количества минерального порошка и песка (иногда мелкого щебня). Температура приготовления и укладки литого асфальта должна быть $220-250^{\circ} \mathrm{C}$. Вязкую массу заливают в подготовленные ямы. Остывая, смесь уплотняется сама собой, без обработки катком. Несомненный плюс технологии в прекрасных адгезионных свойствах даже при морозах и повышенной влажности. Но летом, нагреваясь на солнце доплюс $60{ }^{\circ} \mathrm{C}$, покрытие дороги продавливается колесами транспорта, поэтому специалисты склонны рассматривать литой асфальт как временную меру.

Другой распространенный вариант ремонта дорожных одежд инжекторная, или струйно-инъекционная холодная технология.

Струйно-инъекционная холодная технология заделки выбоин на дорожных покрытиях с помощью битумной эмульсии является сейчас одной из наиболее передовых и прогрессивных. Суть ее состоит в том, что все необходимые операции выполняются рабочим органом одной машины (установки) самоходного или прицепного типа.

Подготовка выбоины к ремонту сводится только к тщательной ее очистке от пыли, мусора и влаги путем продувки высокоскоростной струей воздуха и к обработке поверхности выбоины битумной эмульсией. Операции обрезки, разлома или фрезерования асфальтобетона вокруг выбоины в этой технологии может не производиться.

Сама заделка выбоины осуществляется посредством ее заполнения мелким щебнем, предварительно обработанным битумной эмульсией в камере смешения машины. За счет вовлечения и подачи щебня воздушной струей, его укладка в выбоину происходит с высокой скоростью, что обеспечивает хорошую его упаковку (уплотнение), практически исключающую необходимость в дополнительном использовании виброплит и виброкатков.

Для ямочного ремонта по струйно-инъекционной холодной технологии рекомендуется использовать чистый мелкий щебень фракции 5-10 (15) мм и быстрораспадающуюся катионную или анионную битумную эмульсию 60-ти процентной концентрации.

Струйно-инъекционный метод заделки выбоин можно использовать почти круглый год. Практика его применения показывает, что фактически крепкую и 
долговечную заделку выбоины можно обеспечить даже при температуре воздуха до минус $10-15^{\circ} \mathrm{C}$.

\section{Литература}

1. Шишкин В. Н., Папакин И. Н. Ремонт дорожных покрытий автомобильных дорог при отрицательных температурах // Молодой ученый. — 2016. — №13. — С. 282-284.

2. Леденев В.В., Зубков А.Ф., Однолько В.Г., Евсеев Е.Ю. Технология ремонта дорожных покрытий автомобильных дорог с применением горячих асфальтобетонных смесей. - М.: Издательский дом «Спектр», 2013. - С. 180.

3. Практическое руководство по текущему ремонту асфальтобетонных покрытий автомобильных дорог//Москва, издательство Прима-Пресс-М, 2001.- С. 247. 